\title{
Effectiveness of different control measures against western corn rootworm larvae Diabrotica virgifera virgifera LeConte, 1868
}

\author{
Špela MODIC ${ }^{1}$, Primož ŽIGON ${ }^{1}$, Aleš KOLMANIČ ${ }^{2}$, Tone GODEŠA ${ }^{3}$, Jaka RAZINGER ${ }^{1}$
}

Received December 07, 2017; accepted Februar 24, 2018.

Delo je prispelo 07. decembra 2017, sprejeto 24. februarja 2018.

\begin{abstract}
The Western Corn Rootworm (WCR), Diabrotica virgifera virgifera LeConte, 1868, [Coleoptera, Chrysomelidae], whose larvae cause damage to maize roots, is an important economic insect pest in America and Europe. Its larvae are usually controlled by granular soil insecticides or insecticide-treated seeds. Biological control options, such as entomopathogenic nematodes (EPN) have played an important role as an alternative for synthetic chemical insecticides. Therefore, for the WCR larvae control we compared the effectiveness of inundative biological control on the basis of EPN Heterorhabditis bacteriophora Poinar, 1976 (Rhabditida: Heterorhabditidae); (commercial product Dianem ${ }^{\mathbb{B}}$ ) and the conventional insecticides Force $1.5 \mathrm{~g}$ (active substance tefluthrin) from the group of synthetic pyrethriods and Sonido (active substance thiacloprid) from the group of neonicotinoids. Field experiments were carried out at geographically different locations under different population pressure of the insect pest in a), Bučečovci (Prlekija; Eastern Slovenia) and b), Šmartno (Gorenjska: northern Slovenia). The differences between the treatments were very similar at both locations; although the population of WCR in Gorenjska was approximately 5-fold lower than in Prlekija. The highest number of WCR beetles was caught in the negative control, followed by the product Sonido, Force and Dianem ${ }^{\circledR}$, in decreasing order. Statistical analysis showed that only in the treatment where EPN were used, significantly less WCR was caught than in the control. The results of the WCR larvae control in maize using Heterorhabditis bacteriophora are comparable to published literature. However, the weather conditions in the 2016 trial were very favorable for the development and survival of EPN in the soil.
\end{abstract}

Key words: western corn rootworm; Diabrotica virgifera virgifera; inundative biological control; entomopathogenic nematodes; Heterorhabditis bacteriophora; field trial; Zea mays
IZVLEČEK

\section{UČINKOVITOST RAZLIČNIH METOD ZATIRANJA LIČINK KORUZNEGA HROŠČA Diabrotica virgifera virgifera LeConte, 1868}

Koruzni hrošč (WCR) (Diabrotica virgifera virgifera LeConte, 1868, [Coleoptera, Chrysomelidae], katerega ličinke povzročajo škodo $\mathrm{z}$ objedanjem korenin koruze, je pomemben gospodarski škodljivec $\mathrm{v}$ Ameriki in $\mathrm{v}$ Evropi. Ličinke navadno zatiramo $\mathrm{z}$ granularnimi talnimi insekticidi ali pa insekticidi, ki so naneseni na semena. Biotično varstvo je pomemben način nekemičnega varstva rastlin in med drugim predstavlja pomembno alternativo rabi sintetičnih kemičnih insekticidov. S tem namenom smo v letu 2016 primerjali učinkovitost preplavnega biotičnega varstva na osnovi entomopatogenih ogorčic (Heterorhabditis bacteriophora Poinar, 1976 (Rhabditida: Heterorhabditidae); v Sloveniji na voljo $\mathrm{v}$ obliki tržnega pripravka dianem ${ }^{\circledR}$ ) in konvencionalnih insekticidov (teflutrin (Force 1,5 G) iz skupine sintetičnih piretriodov in tiakloprid (Sonido) iz skupine neonikotinoidov) za zatiranje ličink koruznega hrošča. Poljski poskus je potekal na geografsko različnih lokacijah $\mathrm{z}$ različnim populacijskim pritiskom škodljivca: a), v Bučečovcih v Prlekiji in b), v Śmartnem pri Cerkljah na Gorenjskem. Razlike med obravnavanji so bile zelo podobne na obeh lokacijah, čeprav je bila populacija hroščev na Gorenjskem približno 5-krat manjša kot v Prlekiji. Največ koruznih hroščev smo zabeležili v kontroli. Po padajočem številu ulovljenih hroščev so si sledili pripravki Sonido, Force in Dianem $^{\circledR}$. Statistična analiza je pokazala, da se je le v postopku, kjer smo uporabili entomopatogene ogorčice (EPN) ulovilo statistično manj koruznih hroščev kot $\mathrm{v}$ kontroli. Rezultati zatiranja ličink koruznega hrošča s pripravkom na osnovi vrste $H$. bacteriophora so primerljivi z objavljenimi rezultati študij iz tujine. Pri tem moramo upoštevati dejstvo, da so bile vremenske razmere $\mathrm{v}$ času poskusa ugodne za razvoj in preživetje EPN.

\footnotetext{
Ključne besede: koruzni hrošč; Diabrotica virgifera virgifera; preplavno biotično varstvo; entomopatogene ogorčice; Heterorhabditis bacteriophora; poljski poskus; koruza; Zea mays
}

\footnotetext{
1 Oddelek za varstvo rastlin, Kmetijski inštitut Slovenije, Hacquetova ulica 17, 1000 Ljubljana, Slovenija. Korespondenca: e-mail Spela.Modic@kis.si

2 Oddelek za poljedelstvo, vrtnarstvo, genetiko in žlahtnjenje, Kmetijski inštitut Slovenije, Ljubljana

${ }^{3}$ Oddelek za kmetijsko tehniko in energetiko, Kmetijski inštitut Slovenije, Ljubljana
} 


\section{INTRODUCTION}

LeConte wrote the first formal description of the species Diabrotica v. virgifera in 1868 from beetles collected on pumpkin flowers Cucurbita foetidissima Kunth in Humb near Fort Wallace, Kansas, USA (Smith in Lawrence, 1967). As an insect pest of corn it was referred for the first time in Kolorado in 1909 (Gillette, 1912). The WCR was first discovered in Europe in 1992 in Yugoslavia (Bača, 1994) and has become a threat to maize production areas in many European countries (Kiss et. al., 2005).

Official monitoring of the spreading of WCR in Slovenia has been organized since 1997. Its presence was first reported in 2003 in the eastern, northeastern (Prekmurje, Pomurje) and western part (Gorica) of Slovenia (Urek and Modic, 2004). In 2009 the entire territory of Slovenia was officially declared an infested area. Eight years after the occurrence of WCR the first damage caused by larval feeding was observed in Prekmurje (village Benica). In the next five years damage by larval feeding was observed in more Slovenian regions, mainly in the fields with continuous maize.

In an effort to eradicate or contain the species, legislation has been put into place (U.l. RS 21/04), which forces farmers to rotate their fields (thereby interrupting the life cycle of WCR) or to apply granular soil insecticides or to use insecticide-coated maize seeds (to target the root feeding larvae) or to spray insecticides against the adult (decrease the population density of larvae in the next year) (U. 1. RS 21/04, 2006/565/ES). In the European Union the WCR is no longer considered a "quarantine pest" since 2014
(2014/63/EU), consequently crop rotation is no longer a legally required control measure. In Slovenia, in the measures of the Rural Development Program KOPOP (2014-2020), one of the mandatory requirements is a five-year crop rotation that limits the production of maize in monoculture.

Possible management options to control WCR in Europe include crop rotation, which is one of the oldest control measures (Roush et al., 1990), the development of maize hybrids that possess native resistance against WCR (Ivezić et al., 2009), or the use of conventional chemical insecticides (Levine and Oloumi-Sadeghi, 1991; Sutter et al., 1989). Biological control options have been recommended for WCR in south-eastern Europe in 1998 (Kuhlmann and Burgt, 1998). The use of entomopathogenic nematodes (EPN) against the larvae is one of the most promising alternative biological control options (Toepfer et al., 2012a), in particular species Heterorhabditis bacteriophora Poinar, 1976 which in the field trials reduced the population of the WCR larvae to $65 \%$ and the lodging of plants to $60 \%$, which is comparable with soil insecticides (Toepfer et al., 2005; Kahrer et al., 2015; Toepfer et al., 2010). Importantly, the species $H$. bacteriphora was confirmed in Slovenia in 2009 (Laznik et al., 2009), thereby making it a potential biological agent for controlling larvae of WCR and important alternative to synthetic insecticides.

The aim of our study was to assess $H$. bacteriphorabased biological control and compare its efficacy to two commonly used synthetic insecticides for controlling WCR larvae.

\section{MATERIALS AND METHODS}

\subsection{Study sites and experimental set-up}

The field studies were carried out in geographically different maize growing areas in Slovenia (Table 1).
Both field experiments had a natural pest population of WCR (field A since 2004, field B since 2008) and were four years under corn monoculture production regime.

Table 1: Characteristic of the two field experiments in Slovenia

\begin{tabular}{lll}
\hline Field & $\mathrm{A}$ & $\mathrm{B}$ \\
\hline \hline Location & Bučečovci & Šmartno pri Cerkljah \\
Coordinates & $46^{\circ} 35^{\prime} 07^{\prime \prime} \mathrm{N} 16^{\circ} 06^{\prime} 37^{\prime \prime} \mathrm{E}$ & $46^{\circ} 15^{\prime} 08.8^{\prime \prime} \mathrm{N} 14^{\circ} 29^{\prime} 54.7^{\prime \prime} \mathrm{E}$ \\
Date of sowing/nematode application & $22^{\text {th }}$ April 2016 & $11^{\text {th }}$ May 2016 \\
Cultivar of maize seed & Chapalu & LG 34.90 \\
Field size & 0.11 ha & 0.11 ha \\
Soil texture & silty loam & sandy loam \\
\hline
\end{tabular}


In Bučečovci 'Chapalu' hybrid seeds (FAO 330) were sown by machine Monosem NC classic, at a inter row spacing of $70 \mathrm{~cm}$ and an intra row spacing of $16-17$ $\mathrm{cm}$, resulting in a theoretical stand of 85.000 plants per ha. The maize seeds of the hybrid LG 34.90 (FAO 430) were sown in Šmartno by machine Gaspardo by the same procedure. In total, on both locations, four treatments were conducted in 2016: 1. untreated control;
2. entomopathogenic nematodes (EPN); 3. synthetic pyrethroid insecticide Force 1,5 G (a.i. tefluthrin) and 4. seed coating with a neonicotinoid insecticide Sonido (a.i. thiacloprid) (Table 2). Each treatment was performed in 4 rows $70 \mathrm{~m}$ in length, giving a plot size of $0.028 \mathrm{ha}$; total size of whole experimental fields at both locations was 0.112 ha.

Table 2: WCR management of the two field experiments

\begin{tabular}{|c|c|c|c|}
\hline Field sites & Date of applications & Treatment & Dose \\
\hline \multirow[t]{4}{*}{ A } & $22^{\text {th }}$ April 2016 & 1. Untreated control & / \\
\hline & & 2. H. bacteriophora (EPN) & 2.000.000 nematodes/ha with 4001 water \\
\hline & & 3. Force 1,5 G (a.i. tefluthrin) & $12 \mathrm{~kg} / \mathrm{ha}(1.5 \%$ a.i. $)$ \\
\hline & & 4. Sonido (a.i. thiacloprid ) & $0.1251 / 50000$ seeds (40 \% a.i.) \\
\hline \multirow[t]{4}{*}{$\mathrm{B}$} & $11^{\text {th }}$ May 2016 & 1. Untreated control & I \\
\hline & & 2. H. bacteriophora & 2.000.000 nematodes/ha with 4001 water \\
\hline & & 3. Force 1,5 G (a.i.tefluthrin) & $12 \mathrm{~kg} / \mathrm{ha}(1.5 \%$ a.i. $)$ \\
\hline & & 4. Sonido (a.i. thiacloprid ) & $0.1251 / 50000$ seeds (40 \% a.i.) \\
\hline
\end{tabular}

\subsection{Source and handling of entomopathogenic nematode}

The product Dianem $\AA$, based on entomopathogenic nematode Heterorhabditis bacteriophora, was produced and supplied by e-nema $\mathrm{GmbH}$ (Germany). Infective juveniles of $H$. bacteriophora were shipped by the producer directly to the Agricultural Institute of
Slovenia. Upon arrival, they were stored in their shipping material at $7-9{ }^{\circ} \mathrm{C}$ in darkness until use. They were applied as liquid formulations with application rates $2 \times 10^{9}$ infective juveniles per ha in 400 litres water per ha as a liquid stream directly into seed furrows (Figure 1).

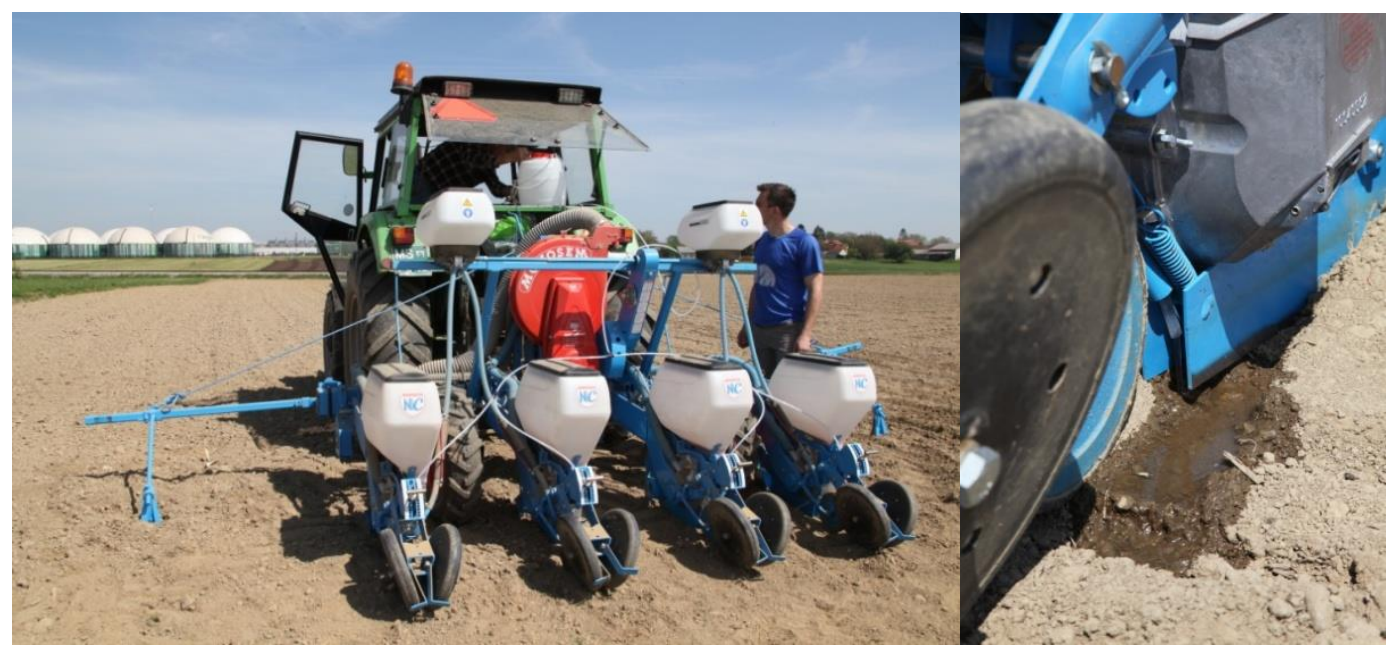

Figure 1: (A, B) Nematodes were applied to the field plots during sowing of maize as a fluid stream into the seed furrows, at a depth of $8-10 \mathrm{~cm}$ 


\subsection{Evaluation}

Efficacy was assessed by comparing the number of emerging adult WCR beetles between treatments and untreated control. Twelve maize plants $\left(1 \mathrm{~m}^{2}\right)$ were covered under gauze cages $(1000 \mathrm{~mm} \times 1000 \mathrm{~mm} \times$ $2300 \mathrm{~mm}$ ). A yellow sticky trap (Trécé) was placed 1.5 $\mathrm{m}$ above soil in the middle of the cage. Adult emergence on yellow sticky trap (Trécé) was recorded once a month.

\subsection{Data analyses}

The absolute number of WCR beetles caught on yellow sticky traps placed in the field cages was analysed by one way ANOVA and Dunnett's multiple comparison post-test in case of normal distribution, or with Kruskall-Wallis test and Dunn's post-test in case the distribution was not normal (Motulsky, 1995). The absolute number of beetles caught in the various treatments was normalized to negative control values, and then the data from both locations were pooled and Log-transformed. The transformed data was normally distributed and analysed by one way ANOVA and Dunnett's multiple comparison post-test. The analyses were carried out with the statistical software GraphPad Prism 5.00 (GraphPad Software, Inc., La Jolla, CA, USA). The number of replicates (n) is indicated in the figure.

\section{RESULTS}

\subsection{Effect of treatments on the number of emerged WCR beetles}

The highest number of WCR beetles was caught in negative control, followed by Sonido and Force, and the least in the EPN treatment. The treatments had a significant effect on the number of WCR beetles caught in the experiment in Šmartno $(\mathrm{P}=0.042)$, but not in
Bučečovci $(\mathrm{P}=0.334)$. No individual treatment had a significant effect on the number of beetles caught at both experimental sites. The average number of WCR beetles caught in the EPN treatment was approximately three times smaller (one third) in Šmartno and two times smaller (half) in Bučečovci compared to negative control catches (Figure 2).
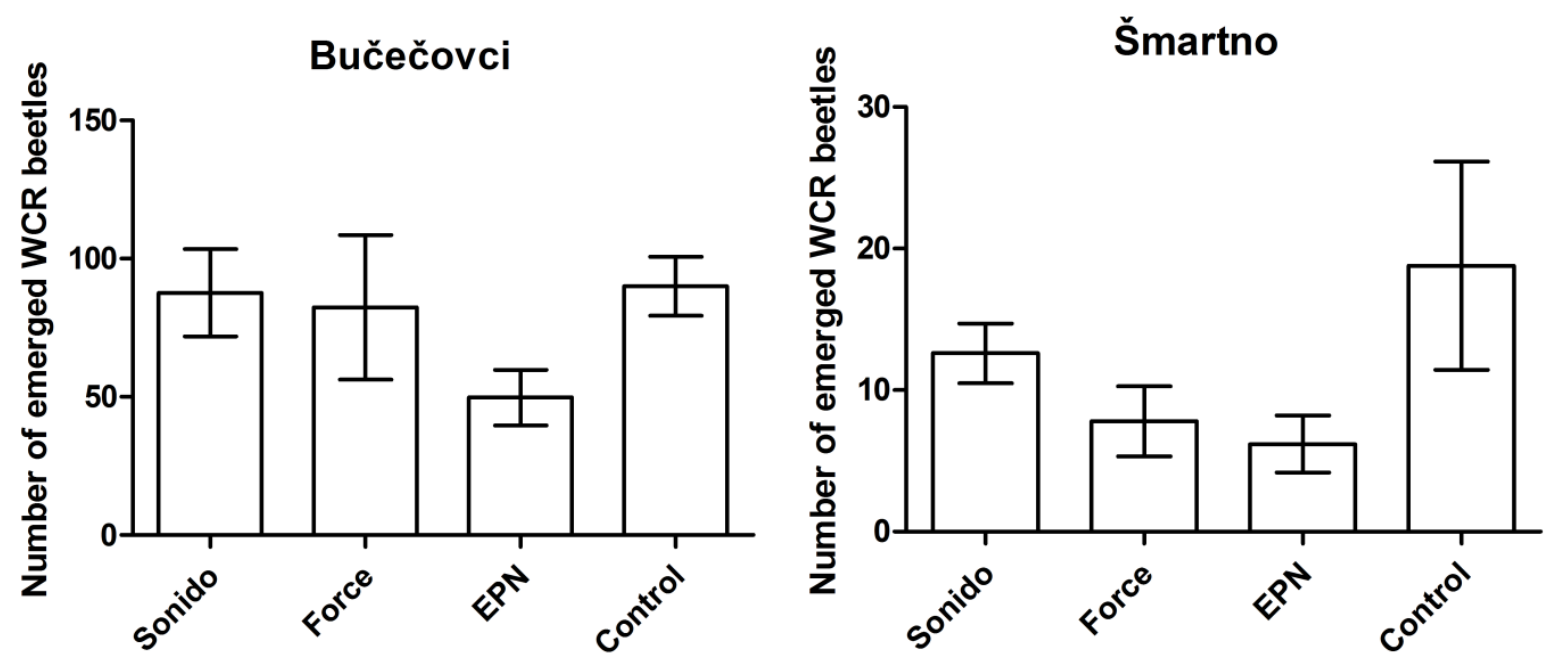

Figure 2: The absolute (cumulative whole season) number of WCR beetles caught on the yellow sticky traps in the field cages. Left: results from Bučečovci experiment; right: results from Šmartno experiment. Error bars were drawn from 5 replicates $(n=5)$.

Differences between treatments, or trends, however, were very similar in Bučečovci and Šmartno. Additionally, markedly different pressure of the WCR population between the locations of the experiments was observed. Because of these two factors the results were normalized to each experiment's negative control and the data from both trials pooled. One-way ANOVA performed on pooled data showed a significant effect of treatments on the number of beetles caught on the yellow sticky traps $(\mathrm{p}=0.017)$. The treatment with EPN resulted in significantly smaller beetle catches (Figure $3)$. 


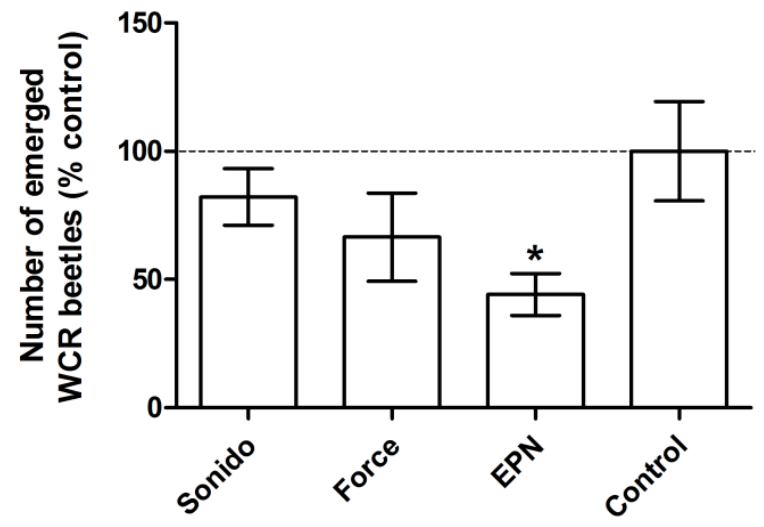

Figure 3: The relative (cumulative whole season) number of WCR beetles caught on the yellow sticky traps in the field cages. Data of experiments from both locations were normalized to their respective controls, and then pooled. Error bars were drawn from 10 replicates $(\mathrm{n}=10)$. Asterisk denotes significant difference from negative control $(\mathrm{P}<$ $0.05)$.

\section{DISCUSION}

Results of the present study provide a comparison between efficacy of a commercial product Dianem ${ }^{\circledR}$ on the basis of EPN Heterorhabditis bacteriophora Poinar (Rhabditida: Heterorhabditidae) with the conventional insecticides Force $1.5 \mathrm{~g}$ (active substance tefluthrin) from the group of synthetic pyrethriods and with Sonido (active substance thiacloprid) from the group of neonicotinoids for the WCR larvae control. We found that the highest number of WCR beetles was caught in negative control, followed by product Sonido, Force and Dianem $^{\mathbb{R}}$, in decreasing order. The evaluation of emerging beetles showed a significant reduction of $55.8 \%$ for Dianem (2.33 emerging beetles per plant or $\left.28.0 \mathrm{~m}^{-2}\right)$ against the untreated control $(4.53$ emerging beetles per plant or $54.4 \mathrm{~m}^{-2}$ ). This result is comparable to published study of Kahrer et al. (2015) where the authors reported a significant reduction in number of emerging beetles amounting $67.6 \%$ for Dianem against the untreated control (81.4 emerging beetles per plant). The much higher emergence rate reported by Kahrer et al. (2015) is probably the result of artificial infestation of the maize plants with WCR eggs.

Crop rotation is the most effective way of controlling WCR populations as its three larval instars feed almost exclusively on maize roots (Moeser and Hibbard, 2005). However, a small percentage of WCR $(<5 \%)$ also disperses into neighbouring fields other than maize, and less than $15 \%$ of all eggs of a population may be laid into such non-maize crop habitats. Despite of this, any crop can be rotated with maize to offer potentially successful control of this pest in Europe (Toepfer et al., 2012b). However, in an Austrian several-season field study, it was reported that crop rotation is no longer a sufficient measure to control WCR, in case of rotation of maize and oil pumpkin (Fragner, 2017). The same study also reports that in 2016, the efficacy of EPN was comparable to certain soil insecticides (cypermethrin and lambda-cyhalothrin), and that EPN use reduced maize lodging on average by $10 \%$ (Fragner, 2017).

Maize is one of the major crops in Slovenia covering about $40 \%$ of all arable land. Sixty percent of maize is grown in north-east Slovenia (Čergan et al., 2008). However, there is the need to plant maize each season, because silage maize presents energetically and economically convenient source of feed for dairy cows and fattening bulls. The maize with its high dry matter yield per hectare fulfils the stakeholder`s demand after large quantities of feed for the increasing numbers of animals per farm in the last decade. Due to fragmented arable land (fields), we can expect the marginal effects of successive corn crops and the occurrence of damages on parts of fields where the surfaces are close together (Modic et al., 2016). Therefore, a system approach is needed to provide sustainable control of the WCR. Several control measures will need to be implemented at the same time: crop rotation, soli treatment, fertilization, corn variety, biological control agents and pheromone mating disruption control. 


\section{CONCLUSION}

The results of WCR larvae control with entomopathogenic nematodes of the species Heterorabditis bacteriophora are promising and comparable to the results of studies from abroad (Kurtz et al., 2007; Toepfer et al., 2010; Pilz et al., 2014; Kahrer et al., 2015). However, we must take into account the fact that the weather conditions in 2016 (high precipitation in May) were favourable for the survival and persistence of the EPN in the soil (soil moisture). Such optimal conditions cannot be expected every year. Repetition of the experiment throughout several seasons is needed.

\section{ACKNOWLEDGEMENTS}

The authors wish to thank: e-nema GMBH as the supplier of the EPN, METROB d.o.o. for technical support, and Michael Lichtenberg, who provided valuable advice on the experimental methodology. The presented results were financially supported by the Administration of the Republic of Slovenia for Food Safety, Veterinary Sector and Plant Protection and Slovenian Ministry of Agriculture, Forestry and Food.

\section{REFERENCES}

Bača, F. (1994). New member of the harmful entomofauna of Yugoslavia, D. virgifera virgifera LeConte (Coleoptera, Chrysomelidae). Zaštita bilja, 45, 125-131.

Čergan, Z., Jejčič, V., Knapič, M., Modic, Š., Moljk, B., Poje, T., Simončič, A., Sušin, J., Urek, G., Verbič, J., Vrščaj, B., Žerjav, M. (2008) . Koruza. Založba kmečki glas: 314 str.

Fragner, H. (2017). Versuche und Erfahrungen aus der Steiermark: Maiswurzelbohrer 2016. Der Pflanzenarzt, 1-2, 24-26.

Gillette, C.P. (1912). Diabrotica virgifera LeConte as a corn rootworm. Journal of Economic Entomology, 54, 4, 364-366. doi:10.1093/jee/5.4.364a

Ivezić, M., Raspudić, E., Bremež, M., Majić, I., Brkić, I., Tollefson, J.J., Bohn, M., Hibbard, B., Šimić, D. (2009). A review of resistance breeding options targeting western corn rootworm (Diabrotica virgifera virgifera LeConte). Agricultural and forest Entomology, 11, 307-311. doi:10.1111/j.1461-9563.2009.00434.x

Kahrer, A., Pilz, C., Heimbach, U., Wechselberger, K., Grabenweger., G. (2015). Five years of experience in biocontrol of the western corn rootworm, Diabrotica virgifera virgifera by entomoparasitic nematodes. New Challenges for Biological Control: 15th Meeting of the IOBC-WPRS Working Group "Microbial and Nematode Control of Invertebrate Pests": Programme and Abstract Book; June 7 - 11, 2015, Riga, Latvia.

Kuhlmann, U., Burgt, W.A.C.M. (1998). Possibilities for biological control of the western corn rootworm, Diabrotica virgifera virgifera LeConte, in Central Europe. Biocontrol News and Information, 19, 59-68.

Kurtz, B., Toepfer, S., Ehlers, R.-U., Kuhlmann, U. (2007). Assessment of establishment and persistence of entomopathogenic nematodes for biological control of western corn rootworm. Journal of Applied Entomology, 131(6), 420-425. doi:10.1111/j.1439-0418.2007.01202.x

Kiss, J, Edwards, C.R., Berger, H.K., Cate, P, Cean, M., Cheek, S., Derron, J., Festic, H., Furlan, L., IgrcBarcic, J., Ivanova, I., Lammers, W., Omelyuta, V., Princzinger, G., Reynaud, P., Sivcev, I., Sivicek, P., Urek, G., Vahala, O. (2005). Monitoring of western corn rootworm (Diabrotica v. virgifera LeConte) in Europe 1992-2003. In S. Vidal, U. Kuhlmann, C. R. Edwards (Eds.), Western corn rootworm: ecology and management (pp. 29-39). Wallingford, UK: CABI Publishing. doi:10.1079/9780851998176.0029

Laznik, Ž., Tóth, T., Lakatos, T., Trdan, S. (2009). Heterorhabditis bacteriophora (Poinar) - the first member from Heterorhabditidae family in Slovenia. Acta agriculturae Slovenica, 93 (2), 181-187. doi:10.2478/v10014-009-0013-1

Levine, E., \& Oloumi-Sadeghi, H. (1991). Management of Diabroticite Rootworms in Corn. Annual Review of Entomology, 36, 229-255. doi:10.1146/annurev.en.36.010191.001305

Modic, Š., Urbančič Zemljič, M., Razinger, J., Kolmanič, A. (2016). Priporočila za obvladovanje koruznega hrošča. Kmetijski inštitut Slovenije. Retrieved from http://www.kis.si/f/docs/Entomologija/Priporocila_ za_obvladovanje_koruznega_hrosca_2017.pdf. 
Moeser, J., Hibbard, B.E. (2005). A synopsis of the nutritional ecology of larvae and adults of Diabrotica virgifera virgifera (LeConte) in the new and old world - nouvelle cuisine for the invasive maize pest Diabrotica virgifera virgifera in Europe? In S. Vidal, U. Kuhlmann, C.R. Edwards (Eds.), Western corn rootworm: ecology and management (pp. 41-65). Wallingford, UK: CABI Publishing. doi:10.1079/9780851998176.0041

Odločbe Komisije 2003/766/ES z dne 24. oktobra 2003 o nujnih ukrepih za preprečevanje širjenja koruznega hrošča Diabrotica virgifera Le Conte v Skupnosti. Uradni list EU, št. 275/49.

Pilz, C., Toepfer, S., Knuth, P., Strimitzer, T., Heimbach, U., Grabenweger, G. (2014). Persistence of the entomoparasitic nematode Heterorhabditis bacteriophora in maize fields. Journal of Applied Entomology, 138, 202-212. doi:10.1111/j.14390418.2012.01743.x

Pravilnik o fitosanitarnih ukrepih za preprečevanje širjenja koruznega hrošča (Uradni list RS, št. $21 / 2004,106 / 2006$ in 22/2009).

Priporočilo Komisije 2006/565/ES z dne 11. avgusta 2006 o zadrževalnih programih za omejitev nadaljnjega širjenja koruznega hrošča Diabrotica virgifera Le Conte na območjih v Skupnosti, kjer je njegova prisotnost potrjena. Uradni list Evropske unije, št. 225/28.

Priporočilo Komisije 2014/63/ES z dne 6. februarja 2014 glede ukrepov za obvladovanje koruznega hrošča Diabrotica virgifera virgifera Le Conte na območjih Unije, kjer je njegova navzočnost potrjena. Uradni list Evropske unije, št. 38/46.

Roush, R.T., Hoy, C.W., Ferro, D.N., Tingey, W.M. (1990). Insecticide resistance in the Colorado potato beetle (Coleoptera: Chrysomelidae): Influence of crop rotation and insecticide use. Journal of Economic Entomology, 83, 315-319. doi:10.1093/jee/83.2.315

Smith, R.F., Lawrence, J.F. (1967). Clarification of the type specimens of Diabroticites (Coleoptera, Chrysomelidae, Galerucinae). University of California publications in entomology, 45, 1-174.
Sutter, G.R., Branson, T.F., Fisher, J.R., Elliot, N.C., Jackson, J.J. (1989). Effect of insecticide treatments on root damage ratings of maize in controled infestations of western corn rootworms (Coleoptera: Chrysomelidae). Journal of Economic Entomology, $\quad 82, \quad$ 1792-1798. doi:10.1093/jee/82.6.1792

Toepfer, S., Gueldenzoph, C., Ehlers, R.-U., Kuhlmann, U. (2005). Screening of entomopathogenic nematodes for virulence against the invasive western corn rootworm, Diabrotica virgifera virgifera (Coleoptera: Chrysomelidae) in Europe. Bulletin of Entomological Research, 95, 473-482. doi:10.1079/BER2005379

Toepfer, S., Burger, R., Ehlers, R.-U., Peters, A., Kuhlmann, U. (2010). Controlling western corn rootworm larvae with entomopathogenic nematodes: effect of application techniques on plant-scale efficacy. Journal of Applied Entomology, 134, 467-480. doi:10.1111/j.14390418.2009.01469.x

Toepfer, S., Hatala-Zseller, I., Ehlers, R.-U., Peters, A., Kuhlmann, U. (2012a). The effect of application techniques on field-scale efficacy: can the use of entomopathogenic nematodes reduce damage by western corn rootworm larvae?. Agricultural and Forest entomology, 12, 389-402. doi:10.1111/j.1461-9563.2010.00487.x

Toepfer, S., Zellner, M., Haye, T., Kuhlmann, U. (2012b). Dispersal and oviposition behaviour of Diabrotica virgifera virgifera in non-maize crops to improve advice and guidelines for crop rotation. In H. Kehlenbeck, Heimbach U., Zellner M. (Eds.) Proceedings International Conference on the German Diabrotica Research Program (pp. 112122). Berlin: Bundesforschungsinstitut für Kulturpflanzen, Julius Kühn-Institut.

Urek, G., Modic, S̆. (2004). Occurrence of the Western Corn Rootworm (Diabrotica virgifera virgifera $\mathrm{Le}$ Conte) in Slovenia. Acta agriculturae Slovenica, 83, 5-13. 